\title{
Influence of Agitation and Aeration on Single Cell Oil Production by Rhodotorula glutinis from Glycerol
}

\author{
Tatiane F. S. R. Bento, Vitor F. M. Viana, Livia M. Carneiro, João Paulo A. Silva* \\ Department of Chemical Engineering, Engineering College of Lorena, University of São Paulo, Lorena/SP, Brazil \\ Email: *jpalves80@usp.br, vitormfv@usp.br, tatianebento@usp.br
}

How to cite this paper: Bento, T.F.S.R. Viana, V.F.M., Carneiro, L.M. and Silva, J.P.A. (2019) Influence of Agitation and Aeration on Single Cell Oil Production by Rhodotorula glutinis from Glycerol. Journal of Sustainable Bioenergy Systems, 9, $29-43$.

https://doi.org/10.4236/jsbs.2019.92003

Received: November 20, 2018

Accepted: May 6, 2019

Published: May 9, 2019

Copyright $\odot 2019$ by author(s) and Scientific Research Publishing Inc. This work is licensed under the Creative Commons Attribution International License (CC BY 4.0).

http://creativecommons.org/licenses/by/4.0/

\begin{abstract}
In the present study, the yeast Rhodotorula glutinis has been assessed with the aim of producing microbial lipids from glycerol under different aeration conditions. For such a purpose, experiments were carried out in shake flasks, under different conditions of agitation (150 to $250 \mathrm{rpm}$ ) and aeration (2.5 to 5.0 of flask volume-to-medium volume ratio). Furthermore, their influence on fermentative parameters (lipid and cell concentration, biomass yield; lipid yield; and lipid volumetric productivity) has been investigated using a $2^{2}$ full factorial design. The statistical analysis has revealed a strong influence of both variables on substrate consumption, lipid accumulation, cell growth and lipid productivity. As a whole, results suggest that higher aeration levels provide greater cell and lipid concentrations, and lipid volumetric productivity. The best results $\left(4.5 \mathrm{~g} / \mathrm{L}\right.$ of lipids and $\mathrm{Q}_{\mathrm{p}}=0.95 \mathrm{~g} / \mathrm{L} \cdot$ day) were achieved at the highest aeration (5.0 flask volume-to-medium volume ratio) and agitation $(250 \mathrm{rpm})$ levels. Their fatty acid profile showed that oleic acid was produced in greater quantity (53.5\%), followed by linoleic acid (18.7\%), palmitic acid (6.8\%) and stearic acid (9.9\%). The microbial oil presented viscosity of 39.3 $\mathrm{cP}$ at $50^{\circ} \mathrm{C}$ and free fatty acid content of $1.93 \% \pm 0.08 \%$. These are significant results and contribute to establishing operational conditions that maximize single-cell oil production from glycerol by Rhodotorula glutinis, i.e. an alternative source as renewable raw material for lipid-based biorefineries.
\end{abstract}

\section{Keywords}

Single-Cell Oil, Rhodotorula glutinis, Aeration, Glycerol, Oleaginous Yeast

\section{Introduction}

Renewable raw material sources have been sought in order to replace petroleum 
in various industrial sectors for quite some time. In this context, the concept of biorefineries arises, i.e. industrial plants capable of processing renewable raw materials on a large scale in order to obtain products of interest to various sectors. Lipid-based biorefineries can use oleaginous raw materials that can be mainly obtained from vegetable oils [1].

An extensive use of vegetable oils as raw material requires large agricultural areas for planting oil crops and harvest periods of over 60 days for processing such crops [2]. Moreover, an increasing demand for raw material and, consequently, for larger cultivation areas could interfere with food production on account of market competition with other crops. Another important aspect that is worth mentioning is its price due to its large impact on the final product, which may correspond to up to $85 \%$ of the price of biofuel [3]. Thus, research on other triglyceride sources that are less costly and non-seasonal, while at the same time achieving higher productivity is fundamental for a more competitive biofuel industry [4] [5].

In addition to using vegetable raw materials, studies have demonstrated that oleaginous microorganisms have great potential for such a purpose. Heterotrophic oleaginous microorganisms, such as yeasts, are able to accumulate lipids rapidly at greater proportions; furthermore, they do not depend on climate, region and are not affected by seasonality, unlike vegetable crops. Such characteristics make these microorganisms potentially competitive as lipid source [6] [7]. Generally speaking, cultures of heterotrophic microorganisms allow obtaining high biomass concentrations and, consequently, lipid concentrations, thus resulting in higher productivity than autotrophic cultures [5] [8]. Li et al. [9] and Tapia et al. [10] assessed microbial oil production by yeasts and reported lipid productivity ranging from 5.76 to $12.96 \mathrm{~g} / \mathrm{L} \cdot$ day, which is ten times higher than those found in studies using microalgae, e.g. Hsieh [11] and Li et al. [9] reported lipid productivity values ranging between 0.051 and $0.134 \mathrm{~g} / \mathrm{L} \cdot$ day, respectively. High productivity of heterotrophic microorganisms shows that yeasts are potentially promising for large scale lipid production. Furthermore, oleaginous yeasts can utilize a wide variety of alternative carbon sources, such as glycerol, thus being an important feature for being used in biorefineries [12].

According to Rawat et al. [13], the use of by-products as raw materials is an important strategy for improving the competitiveness of biodiesel production from microbial oils. Among possible substrates to be used, glycerol stands out due to its availability to biodiesel production plants ( 0.1 tons per tonne of biodiesel), and its use for producing lipids from microorganisms represents a significant advance for introducing technologies required by lipid-based biorefineries [14] [15].

Oxygen availability by culturing oleaginous yeast is a parameter that exerts great influence on microbial growth, lipid productivity and composition. Oxygen availability in the culture medium generally has a positive correlation with biomass concentration and lipid productivity of yeast [16]. It can also influence fatty acid composition of lipids produced in the culture medium [17]. According 
to Zara et al. [18], greater oxygen availability while culturing two different strains of $S$. cerevisiae rendered greater lipid production and led to an increase in the proportion of unsaturated fatty acids in comparison with the total amount of oil production. According to these authors, aeration level directly influenced gene expression involved in coding enzymes linked to lipid biosynthesis, which leads to different fatty acid composition in cultures under different aeration conditions. According to Ageitos et al. [19], the relationship between oxygen availability and lipid production, as well as the composition of fatty acids present in oils, seems to vary according to the species of yeast, thereby it must be determined empirically. Thus, aeration level is a parameter of utmost importance to be considered for efficient processes to obtain microbial oils.

In this context, the present study aimed to assess the influence of oxygen availability on lipid production by Rhodotorula glutinis NRRL Y-12905 from glycerol. Although several pieces of research have been published about microbial oil production by yeast, the present work demonstrates a systematic study on using statistical tools for evaluating and determining optimal process conditions for obtaining single cell oil.

\section{Material and Methods}

\subsection{Microorganisms and Inoculum Preparation}

The yeast Rhodotorula glutinis NRRL Y-12905 has been used as microorganism in experiments. It was provided by the USDA (United States Department of Agriculture), Peoria, Illinois, and kept on malt extract agar slant at $4^{\circ} \mathrm{C}$. The inoculum was prepared by transferring cells from malt extract agar to $250 \mathrm{~mL}$ Erlenmeyer flasks containing $50 \mathrm{~mL}$ of a culture medium composed of (g/L) glycerol (30.0), yeast extract (3.0), $\mathrm{MgSO}_{4} \cdot 7 \mathrm{H}_{2} \mathrm{O}(1.0)$ and $\left(\mathrm{NH}_{4}\right)_{2} \mathrm{HPO}_{4}$ (3.0). The flasks were incubated for 24 hours at $30^{\circ} \mathrm{C}$ and $200 \mathrm{rpm}$. Afterwards, the cells were recovered by centrifugation (2000 $\mathrm{xg}$ for 10 minutes) and resuspended in sterile distilled water and transferred to the culture medium so as to reach an initial cells concentration of about $1 \mathrm{~g} / \mathrm{L}$.

\subsection{Conditions of Fermentation Assays}

The influence of oxygen availability on lipid production from glycerol by Rhodotorula glutinis has been evaluated through the design of experiments and response surface methodology. Fermentation assays were carried out according to a face-centered $2^{2}$ full factorial design with center points in triplicate. In this study, agitation and aeration effects on substrate consumption, cell growth, lipid accumulation, biomass yield ( $\mathrm{Y}_{\mathrm{X} / \mathrm{S}}$ - biomass yield on glycerol consumed; $\mathrm{g} / \mathrm{g}$ ) and lipid yield ( $\mathrm{Y}_{\mathrm{P} / \mathrm{S}}$-lipid yield on glycerol consumed; $\mathrm{g} / \mathrm{g}$ ) and lipid volumetric productivity were assessed. Statistica 13 (license: JKK510H198630AR-B) was used in the statistical analysis.

Fermentation assays were performed in 250-mL Erlenmeyer flasks containing 50,67 or $100 \mathrm{~mL}$ of a fermentation solution medium composed of (g/L) glycerol 
(70.0), yeast extract (3.0), $\mathrm{MgSO}_{4} \cdot 7 \mathrm{H}_{2} \mathrm{O}$ (1.0), $\left(\mathrm{NH}_{4}\right)_{2} \mathrm{HPO}_{4}$ (3.0) and $\mathrm{KH}_{2} \mathrm{PO}_{4}$ (20.0) inoculated with $1 \mathrm{~g} / \mathrm{L}$ cells. The inoculated flasks were incubated for $120 \mathrm{~h}$ in a rotary shaker at $30^{\circ} \mathrm{C}$. The different conditions of agitation (150 to $250 \mathrm{rpm}$ ) and aeration (2.5 to 5.0 of flask volume-to-medium volume ratio) employed in essay were varied according to a factorial design. Throughout the essay, samples were taken at every $24 \mathrm{~h}$ for assessing lipid and glycerol concentrations, and cell growth determinations.

\subsection{Analyses}

Cell concentration was determined by measuring the fermentation broth UV-spectrophotometric absorbance at $600 \mathrm{~nm}$, which was correlated to a calibration curve (dry weight by optical density).

Glycerol concentration was determined by High Performance Liquid Chromatography (HPLC) in an Agilent chromatograph equipped with a Bio-Rad Aminex HPX-87H column $(300 \times 7.8 \mathrm{~mm})$ and a refractive index detector. Operation conditions were $45^{\circ} \mathrm{C}$ of temperature, $0.005 \mathrm{~mol} / \mathrm{L}$ of sulfuric acid as eluent at flow rate of $0.6 \mathrm{~mL} / \mathrm{min}$ and sample volume of $20 \mu \mathrm{L}$.

Total lipids were extracted from cells by the Bligh \& Dyer method [20]. The extracted lipid was dried at $80^{\circ} \mathrm{C}$ for solvent evaporation and quantified by the colorimetric staining method through the Sulfo-phospho-vanillin assay described by Knight et al. [21]. The absorbance of samples was determined at 525 $\mathrm{nm}$ with white water and total lipid concentration was calculated using a calibration curve.

Lipid was extracted from cells by the Bligh \& Dyer method to analyze fatty acid profile, absolute viscosity and acidity index [20]. The extracted lipid was dried on a rotary evaporator at $60^{\circ} \mathrm{C}$ to remove solvent, which has been subsequently dried to constant weight.

FAMEs were prepared by methyl transesterification of lipids [22]. Transesterification was performed by adding $2.0 \mathrm{~mL}$ of methanol containing $\mathrm{HCl} 3 \mathrm{~N}$ with about $50 \mathrm{mg}$ of lipid. This mixture was then incubated at $60^{\circ} \mathrm{C}$ for 14 hours. After cooling, $1 \mathrm{~mL}$ of $\mathrm{K}_{2} \mathrm{CO}_{3}(6 \%)$ was added. FAMEs were extracted by adding $0.6 \mathrm{~mL}$ of hexane. The mixture was agitated and centrifuged at $1000 \times \mathrm{g}$ for 10 min. An amount of the phase containing hexane was removed for analysis by gas chromatography, which was conducted by a gas chromatograph (Clarus 580 CG, Perkin Elmer) equipped with a Perkin Elmer Elite 5 capillary column (5\% diphenyl/95\% dimethyl polysiloxane, $30 \mathrm{~m}$ long, internal diameter of $0.25 \mathrm{~mm}$, $0.25 \mu \mathrm{m}$ film) and a FID. Nitrogen was used as carrier gas at $0.5 \mathrm{~mL} / \mathrm{min}$ and heating column at temperatures of $120^{\circ} \mathrm{C}(0.5 \mathrm{~min}), 120^{\circ} \mathrm{C}-280^{\circ} \mathrm{C}\left(3^{\circ} \mathrm{C} / \mathrm{min}\right)$ and $280^{\circ} \mathrm{C}(6.17 \mathrm{~min})$.

The absolute viscosity of microbial oil was determined with a Brookfield Model LVDVII viscometer (Brookfield Viscometers Ltd., England) using the CP 52 cone. Measurements were made at $50^{\circ} \mathrm{C}$ in triplicate. To verify the Newtonian fluid behavior, the obtained data (viscosity, strain rate and shear stress) were 
adjusted to Equation (6), where: where: $K$ is the consistency index, $\gamma$ is strain rate, $n$ is the angular coefficient and $\tau$ is shear stress).

$$
\tau=K \cdot \gamma^{n}
$$

Acidity index was determined according to the AOCS methodology [23] by titration. A $0.20 \mathrm{~g}$ sample of oil was solubilized in $25.0 \mathrm{~mL}$ of an ethyl ether/ethyl alcohol (2:1) solution. The mixture was titrated with potassium hydroxide $(0.02$ $\mathrm{mol} / \mathrm{L}$ ) using phenolphthalein as indicator. Acidity index and free fatty acid content were calculated according to the mass of potassium hydroxide (in milligrams) used to neutralize an oil sample (in grams). Equations (7) and (8) were used to calculate acidity index and free fatty acid content, respectively.

$$
\begin{aligned}
& \mathrm{AI}\left(\mathrm{mg}_{\text {Кон }} / \mathrm{g}\right) \\
& =\frac{\text { Alkali volume }(\mathrm{mL}) \times \text { Alkali molarity }(\mathrm{mol} / \mathrm{L}) \times(56.1 \mathrm{~g} / \mathrm{mol})}{\text { Sample weight }(\mathrm{g})}
\end{aligned}
$$

FFA \%

$$
=\frac{100 \times \text { Alkali volume }(\mathrm{mL}) \times \text { Alkali molarity }(\mathrm{mol} / \mathrm{L}) \times(282 \mathrm{~g} / \mathrm{mol})}{\text { Sample weight }(\mathrm{g})}
$$

\section{Results and Discussion}

\subsection{Effect of Agitation/Aeration on Lipid Production}

Table 1 shows the experimental conditions and response variables considered by the $2^{2}$ full factorial design to assess the influence of oxygen availability on lipid

Table 1. Experimental design, with the real and coded values of the variables, for evaluation of the agitation/aeration effect on Cell and Lipid concentrations, Consumption of glycerol, $Y_{\mathrm{X} / \mathrm{S}}$ (biomass yield on glycerol consumed; g/g); $Y_{\mathrm{P} / \mathrm{S}}$ (lipid yield on glycerol consumed; g/g) and Lipid productivity $\left(Q_{P}\right)$ by Rhodotorula glutinis from glycerol. $X_{1}$-Agitation; $X_{2}-$ Aeration.

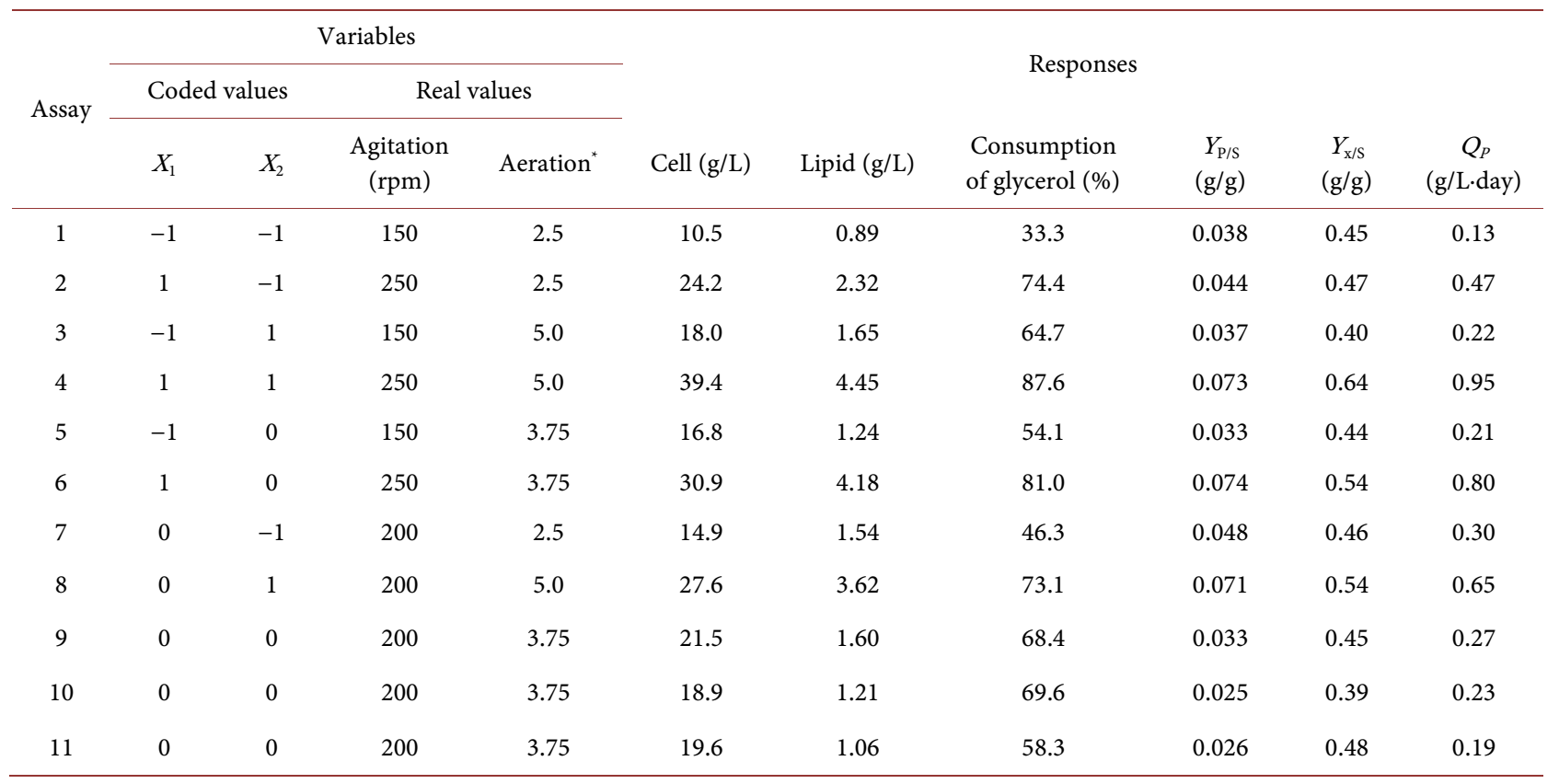

*Aeration is defined as the ratio between the volume of the Erlenmeyer flask and the volume of fermentation medium used in the experiments. 
production by yeast Rhodotorula glutinis. The following response variables were assessed: cell and lipid concentration; substrate consumption; lipid yield; biomass yield; and lipid productivity. The yeast was able to accumulate lipids during the observed culture period in all conditions, but there was a great variation in the final lipid and cell concentrations, thus demonstrating the influence of aeration on microbial oil production. A maximum lipid concentration of 4.45 $\mathrm{g} / \mathrm{L}$ was obtained under higher oxygen availability conditions (level +1 of both variables, $X_{1}$ and $X_{2}$ ). On the other hand, under lower oxygen availability conditions (level -1 of both variables), there were limitations in cell growth and in lipid accumulation if compared to higher aeration conditions. Increased oxygen availability conditions provided a lipid accumulation about five times greater than that accumulated by yeast under lesser aeration conditions. These data indicate a positive effect of increased aeration on microbial oil production and cell growth.

Agitation and aeration effects have been assessed more carefully through statistical tools using the response surface methodology. The Pareto charts shown in Figure 1 estimate the effects of studied variables on cell concentration (Figure 1(a)), lipid concentration (Figure 1(b)), substrate consumption (Figure 1(c)), lipid productivity (Figure 1(d)) and biomass yield (Figure 1(e)) and lipid yield (Figure 1(f)). For this analysis, significant terms are those where $t_{\text {calculated }}$ (represented by bars in the Pareto chart) values are higher than $t_{\text {table }}$ values (represented as a line at $P=0.05$ in the Pareto chart) for Student's distribution with $95 \%$ confidence interval.

The Pareto chart in Figure 1(a) shows estimates of the effect of studied variables on cell concentration. For the cell concentration response variable, linear effects of Agitation $\left(X_{1}\right)$ and Aeration $\left(X_{2}\right)$ variables, as well as the Agitation quadratic effect $\left(X_{1} * X_{1}\right)$ and the effect of an interaction between Agitation and Aeration $\left(X_{1}{ }^{*} X_{2}\right)$ achieved of $95 \%$ confidence interval. Moreover, only the Aeration quadratic effect $\left(X_{2}\right)$ was not statistically significant.

By analyzing the Pareto chart as regards response variables of lipid accumulation (Figure 1(b)) and substrate consumption (Figure 1(c)), it was found that linear terms of Agitation $\left(X_{1}\right)$ and Aeration $\left(X_{2}\right)$ variables were significant at 95\% confidence interval. It was also observed that quadratic terms as well as interaction term $\mathrm{AB}$ presented no significant effects within the variation range observed herein.

As for the lipid productivity response variable (Figure 1(d)), the Pareto Chart analysis demonstrated that linear effects of Agitation $\left(X_{1}\right)$ and Aeration $\left(X_{2}\right)$ together with the effect of an interaction between Agitation and Aeration $\left(X_{1}{ }^{\star} X_{2}\right)$ presented statistical significance at $95 \%$ confidence interval. It is important to emphasize that the Agitation quadratic effect $\left(X_{1} * X_{1}\right)$ presented a value that is very close to the limit of the analysis, so it was decided to maintain this effect in the model that describes $Q_{p}$ behavior as a function of studied variables.

For both response variables, i.e. biomass yield $\left(Y_{\mathrm{X} / \mathrm{s}}\right)$ and lipid yield $\left(Y_{\mathrm{P} / \mathrm{S}}\right)$, the Pareto chart (Figure 1(e) and Figure 1(f), respectively) analysis has revealed 


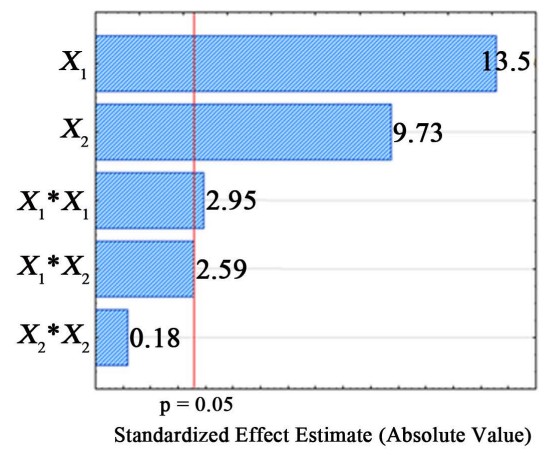

(a)

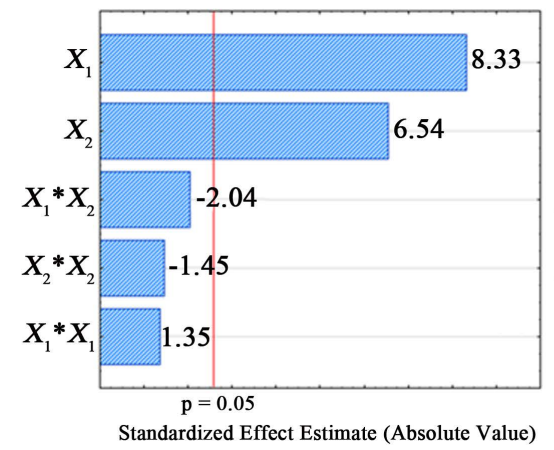

(c)

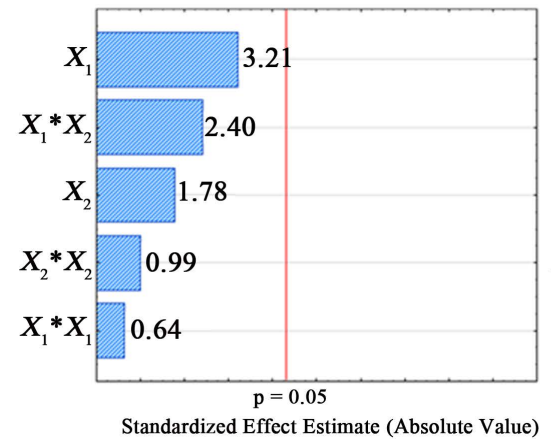

(e)

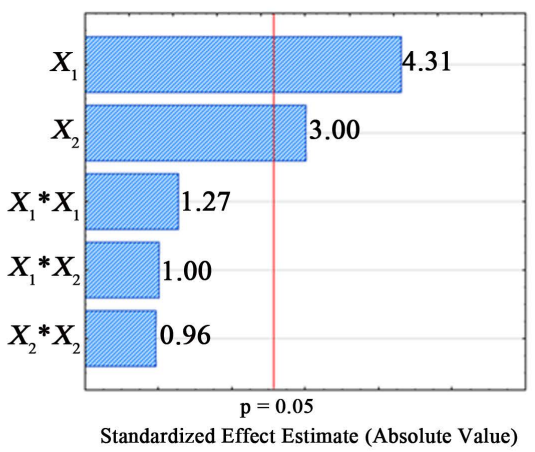

(b)

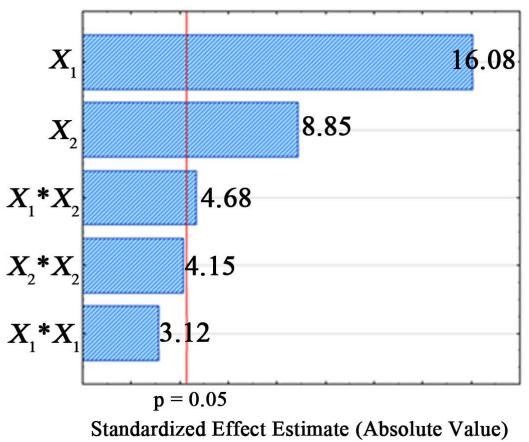

(d)

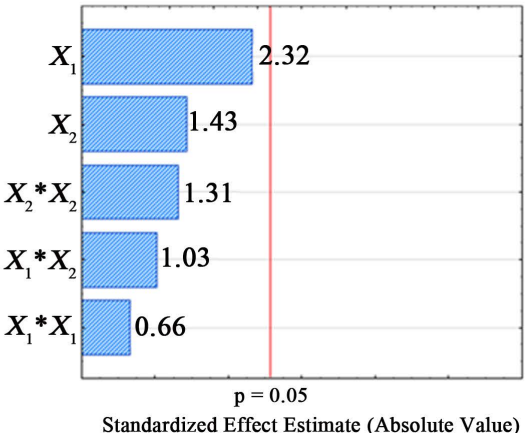

(f)

Figure 1. Pareto chart for the effects of Agitation $\left(X_{1}\right)$ and Aeration $\left(X_{2}\right)$, and their interactions, during the cultivation of Rhodotorula glutinis, on the Cell growth (a); Lipid accumulation (b); Consumption of glycerol (c); Lipid productivity (d) $Y_{\mathrm{X} / \mathrm{S}}(\mathrm{e})$ and $Y_{\mathrm{P} / \mathrm{S}}(\mathrm{f})$.

that none of the variables were significant at $95 \%$ confidence interval. Such behavior may be due to the fact that substrate consumption, cell growth and lipid accumulation varied together, so that, within the variation range observed, lipid yield or biomass yield presented similar values, regardless of aeration condition.

With respect to terms considered as significant by the Pareto chart analysis, mathematical models capable of describing the behavior of response variables of cell concentration, lipid accumulation, substrate consumption and lipid productivity (Equations (1)-(4), respectively) were developed as a function of Agitation and Aeration variables within the studied region. The analysis of variance of models (ANOVA) is presented in Table 2, through which it was found that, at 95\% confidence interval, all mathematical models were significant and presented no lack of fit. The models showed values of coefficient of determination of $98 \%$, 
Table 2. Analysis of variance of the models obtained by $2^{2}$ full design with three replicates in the center point, for the responses: cell and lipid concentrations, consumption of glycerol, and lipid productivity by Rhodotorula glutinis from glycerol.

\begin{tabular}{ccccc}
\hline \multirow{2}{*}{$\begin{array}{c}\text { ANOVA } \\
\text { analysis parameters }\end{array}$} & \multicolumn{4}{c}{ Responses of models } \\
\cline { 2 - 5 } & Cell $^{*}(\mathrm{~g} / \mathrm{L})$ & $\operatorname{Lipid}^{*}(\mathrm{~g} / \mathrm{L})$ & Consumption of glycerol ${ }^{*}(\%)$ & $Q_{P}^{*}(\mathrm{~g} / \mathrm{L} \cdot$ day $)$ \\
\hline Model $P$-value & $<0.0005$ & 0.004 & $<0.0005$ & 0.005 \\
Lack of fit $P$-value & 0.551 & 0.104 & 0.681 & 0.076 \\
$\mathrm{R}^{2}$ & 0.9834 & 0.7458 & 0.9015 & 0.8926 \\
\hline
\end{tabular}

${ }^{\star}$ Significant at $95 \%$ confidence; $\mathrm{P}<0.05$.

$75 \%, 90 \%$ and $89 \%$ for cell concentration, lipid concentration, substrate consumption and lipid productivity response variables, respectively. Based on these mathematical models, response surface charts shown in Figure 2 were drawn.

$$
\begin{gathered}
\operatorname{Cell}(\mathrm{g} / \mathrm{L})=20.5+8.2 X_{1}+5.9 X_{2}+2.8 X_{1}^{2}+1.9 X_{1} X_{2} \\
\operatorname{Lipid}(\mathrm{g} / \mathrm{L})=2.16+1.19 X_{1}+0.83 X_{2} \\
\text { Glycerol consumption }(\%)=64.6+15.2 X_{1}+11.9 X_{2} \\
Q_{P}(\mathrm{~g} / \mathrm{L} \cdot \text { day })=0.33+0.28 X_{1}+0.15 X_{2}+0.13 X_{1}^{2}+0.10 X_{1} X_{2}
\end{gathered}
$$

Figure 2(a) shows a response surface chart that describes cell production as a function of Agitation $\left(X_{1}\right)$ and Aeration $\left(X_{2}\right)$ for 120 hours of culture time. Increases in both Agitation and Aeration provided greater cell concentration obtained at the end of the culture. This increase in cell concentration was more pronounced when both variables, $X_{1}$ and $X_{2}$, were increased simultaneously. Such behavior demonstrates the contribution of effects of an interaction between Agitation $\left(X_{1}\right)$ and Aeration $\left(X_{2}\right)$ variables on cell concentration response variable. Within the variation range under study, maximum cell concentration (39.4 $\mathrm{g} / \mathrm{L}$ ) was obtained at the highest level of both variables, aeration ( $V_{\text {flask }} / V_{\text {medium }}$ ratio of 5.0) and agitation (250 rpm). In fact, higher oxygen availability conditions tend to favor cell growth, since oleaginous yeasts are aerobic microorganisms [24] [25]. These results demonstrate that oxygen availability may be a limiting factor for cell growth, and efficient oxygen transfer systems are essential for the development of cultures with high cell concentration.

Figure 2(b) shows the response surface that relates the concentration of lipids accumulated by yeast after 120 hours of culture as a function of Agitation $\left(X_{1}\right)$ and Aeration $\left(X_{2}\right)$ used in the culture. By analyzing the behavior described by the response surface chart, it is found that an increase in both variables, $X_{1}$ and $X_{2}$, positively influenced lipid accumulation by yeast. Within the observed variation range, lipid concentration ranged from $0.9 \mathrm{~g} / \mathrm{L}$ to $4.5 \mathrm{~g} / \mathrm{L}$. Maximum lipid concentration $(4.5 \mathrm{~g} / \mathrm{L})$ was obtained under higher aeration conditions, i.e. at the highest level of both variables. Saenge et al. [24] reported an assessment of lipid production by the yeast Rhodotorula glutinis from glycerol under different oxygen availability conditions. Aeration variation in the medium (measured in vvm) 


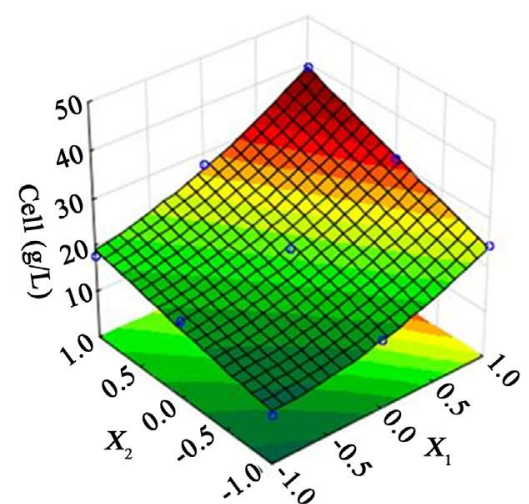

(a)

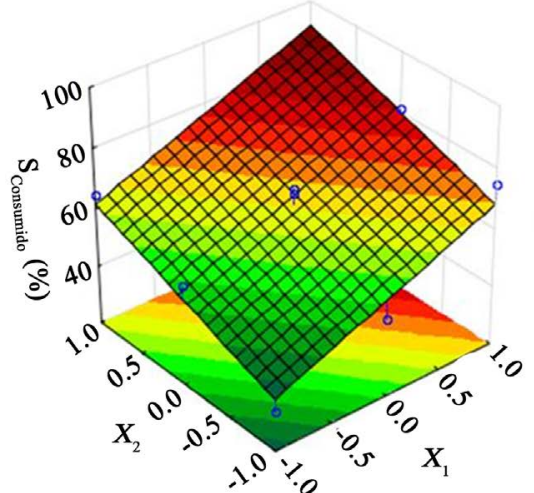

(c)

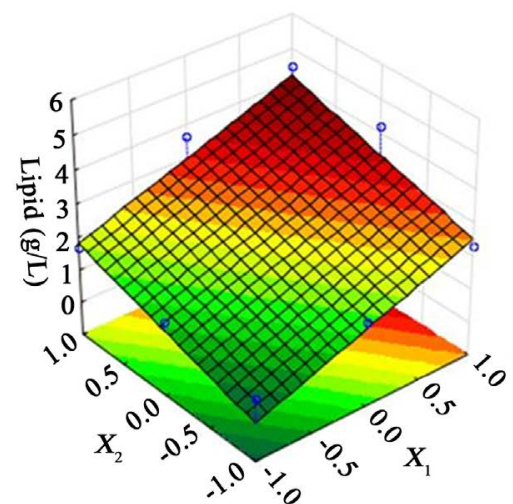

(b)

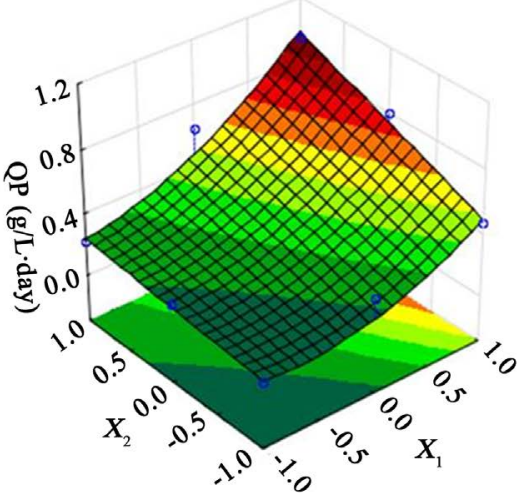

(d)

Figure 2. Response surfaces described by the models representing the Cell growth (a); Lipid accumulation (b); Consumption of glycerol (c); and Lipid productivity (d) as function of the aeration/agitation level.

was used to assess oxygen availability to the yeast. Thus, these authors report that, for batch cultures, an increase in aeration from 0 to $2 \mathrm{vvm}$ led to higher cell concentration and accumulated lipid concentration. The authors also reported that maximum lipid concentration reached in batch cultures was $4.32 \mathrm{~g} / \mathrm{L}$, i.e. a very similar result to that found herein.

Figure 2(c) shows the response surface that describes substrate consumption by yeast after 120 hours of culture as a function of the Agitation $\left(X_{1}\right)$ and Aeration $\left(X_{2}\right)$ variables. The behavior of substrate consumption as a function of studied variables was similar to that observed for lipid accumulation. Substrate consumption was generally favored by an increase in both variables, Agitation $\left(X_{1}\right)$ and Aeration $\left(X_{2}\right)$. Glycerol consumption varied from 33\% under lower oxygen availability conditions ( $X_{1}$ and $X_{2}$, at level -1$)$ to $88 \%$ under greater oxygen availability conditions $\left(X_{1}\right.$ and $X_{2}$ at level +1$)$.

Figure 2(d) shows the response surface chart that depicts volumetric lipid productivity as a function of Agitation $\left(X_{1}\right)$ and Aeration $\left(X_{2}\right)$ used in the culture. In the response surface analysis, it was observed that an increase in both evaluated variables positively influenced volumetric lipid productivity. Within the studied range of conditions, volumetric productivity varied between 0.13 g/L.day and $0.95 \mathrm{~g} / \mathrm{L} \cdot$ day. As regards cell concentration, lipid accumulation and 
substrate consumption response variables, lipid productivity was favored under higher oxygen availability conditions. Under such conditions (level +1 of $X_{1}$ and $X_{2}$ ), a lipid productivity of $0.95 \mathrm{~g} / \mathrm{L} \cdot$ day was achieved.

As a whole, the results suggest that higher cell and lipid concentrations, as well as higher volumetric lipid productivity, could be achieved by providing the culture medium with greater aeration levels. It was also observed that, within the studied range, there were no significant variations in biomass yield $\left(\mathrm{Y}_{\mathrm{X} / \mathrm{S}}\right)$ and lipid yield $\left(\mathrm{Y}_{\mathrm{P} / \mathrm{S}}\right)$. Notwithstanding, it was found that lipid production can be favored by higher aeration conditions, cultures in shaken flasks did not enable tests with greater agitation (maximum possible agitation at $250 \mathrm{rpm}$ ). The tendency observed in the analysis of results suggests that an improvement in lipid production can be achieved under higher aeration conditions. Thus, yeast cultures performed on bioreactors which could provide higher aeration levels, or even the use of oxygen enriched air, are potentially promising alternatives to make important improvements in the process productivity. In fact, higher aeration levels have been reported as favorable conditions for lipid production. Machado Junior [26] studied the influence of aeration on Yarrowia lipolytica NRRL YB-423 yeast for biomass production using glycerin as carbon source. Cultures were conducted in a Biostat B bioreactor. The authors analyzed the influence of agitation (100, 200 and $300 \mathrm{rpm})$ and aeration (0.5 vvm, $1.0 \mathrm{vvm}$ and $1.5 \mathrm{vvm})$ on cell growth and lipid content. Among the evaluated conditions, optimal results were achieved in cultures conducted at $200 \mathrm{rpm}$ of agitation and aeration of $1 \mathrm{vvm}$. Under these conditions, $19.14 \mathrm{~g} / \mathrm{L}$ of cell biomass and lipid productivity of $0.76 \mathrm{~g} / \mathrm{L} \cdot$ day were obtained. In present study, the volumetric productivity in lipids $(0.95 \mathrm{~g} / \mathrm{L} \cdot$ day $)$ was higher than reported by Machado Junior $(0.76 \mathrm{~g} / \mathrm{L} \cdot$ day $)$. This higher productivity obtained in present study can be related not only to the aeration conditions, but also by the different species of yeasts used in the studies.

Magdouli et al. [27] also investigated the influence of oxygen availability on lipid production by the yeast Yarrowia lipolytica from glycerol. In their studies, cultures were conducted in bioreactors equipped with a dissolved oxygen controller in two stages: during the first 24 hours, oxygen saturation was maintained at $60 \%$, and afterwards it was adjusted to three different conditions $(15 \%-20 \%$, $30 \%$ - 35\%, and 40\% - 60\%). The highest lipid concentration (8.0 g/L) was achieved for cultures under oxygen saturation of 30-35\%. Greater lipid accumulation in intermediate aeration condition suggests that oxygen availability can be adjusted to optimized levels, thus contributing to establish conditions of greater bioconversion efficiency. These results highlight the importance of studies to evaluate oxygen availability conditions on single-cell oils productions by yeast to establish efficient process conditions.

\subsection{Microbial Oil Analysis}

By analyzing the microbial oil produced by the yeast Rhodotorula glutinis, it was found fatty acids with chain size ranging from ten to eighteen carbons with different saturation degrees (Table 3 ). The microbial oil consists mostly of 
Table 3. Fatty acid profile analysis from single-cell oil by Rhodotorula glutinis NRRL Y-12905, and comparison with literature data.

\begin{tabular}{cccccc}
\hline Fatty acid & & $\begin{array}{c}\text { Present } \\
\text { study }\end{array}$ & $\begin{array}{c}\text { Sitepu } \\
(2013)[29]\end{array}$ & $\begin{array}{c}\text { Kot et al.; } \\
(2016)[28]\end{array}$ & $\begin{array}{c}\text { Zhang et al.; } \\
(2014)[30]\end{array}$ \\
\hline Caprylic Acid & C8:0 & n.d. & 0.0 & n.r. & n.r. \\
Capric Acid & C10:0 & $0.02 \pm 0.01$ & 0.0 & n.r. & n.r. \\
Lauric Acid & C12:0 & $0.07 \pm 0.01$ & 0.0 & 0.0 & n.r. \\
Myristic Acid & C14:0 & $0.87 \pm 0.02$ & 1.7 & 0.4 & 0.7 \\
Palmitic Acid & C16:0 & $16.83 \pm 0.06$ & 12.0 & 24.3 & 16.5 \\
Palmitoleic acid & C16:1 & n.d. & n.r. & 0.2 & 0.4 \\
Stearic Acid & C18:0 & $9.97 \pm 0.05$ & 5.5 & 10.1 & 3.7 \\
Oleic Acid & C18:1 & $53.54 \pm 0.02$ & 54.7 & 53.2 & 51.3 \\
Linoleic Acid & C18:2 & $18.73 \pm 0.03$ & 17.1 & 6.8 & 21.6 \\
Arachidonic acid & C20:0 & n.d. & n.r. & 0.3 & n.r. \\
\hline
\end{tabular}

n.d.-not detected; n.r.- not reported.

unsaturated fatty acids, which correspond to $72 \%$. Four fatty acids (palmitic acid, stearic acid, oleic acid and linoleic acid) constitute about $99 \%$ of lipid constituents. Among which, oleic acid (C18: 1) was the most commonly found fatty acid, i.e. about $53.5 \%$, followed by linoleic (C18: 2), palmitic (C16: 0) and stearic (C18: 0) with 18.7\%, 16.8\%, 9.9\%, respectively. Traces of capric (C10:0) and lauric (C12: 0 ) acids were also detected, $0.02 \%$ and $0.07 \%$, respectively. These results are in agreement with previously reported data in literature for the yeast Rhodotorula glutinis, as described by Kot et al. [28], Sitepu [29] and Zhang et al. [30]. The authors reported that the main fatty acids produced by yeast were palmitic (16: 0), stearic (18:0), oleic (18:1), linoleic (18:2), which together account for over $80 \%$ of fatty acids that make up the lipid fraction. These results show that cultures performed under optimized oxygen supply conditions allowed obtaining lipids whose fatty acid profile is similar to those reported in literature. The results also show that the use of glycerol as carbon source for microbial oil production had no significant influence on the fatty acid profile contained in the lipid fraction.

According to the rheological analysis of the microbial oil obtained from Rhodotorula glutinis, a Newtonian fluid behavior was observed with constant viscosity at deformation rate ranging between 100 and $360 \mathrm{~s}^{-1}$. This behavior is in agreement with literature data, since oils and fats commonly present Newtonian fluid behavior [31]. The average viscosity of the microbial oil produced by the yeast $R$. glutinis was $39.3 \pm 0.4 \mathrm{cP}$ at $50^{\circ} \mathrm{C}$. This is a higher viscosity value than that observed for vegetable oils reported by Brock et al. [32], who had assessed the viscosity of vegetable oils at $50^{\circ} \mathrm{C}$, such as soybean $(22.3 \mathrm{cP})$, corn $(24.8 \mathrm{cP})$, sunflower $(21.3 \mathrm{cP})$, rice $(24.5 \mathrm{cP})$, cotton $(24 \mathrm{cP})$, olive $(26.2 \mathrm{cP})$ and canola $(25.2 \mathrm{cP})$ oils. Microbial oils generally exhibit higher viscosity than vegetable oils [33] [34]. On the other hand, the oil produced by $R$. glutinis achieved lower vis- 
cosity than microbial oils produced by filamentous fungi and cyanobacteria. In their studies, Da-Rós et al. [33] evaluated microbial oil production from different cyanobacteria, including Trichormus sp. CENA77, Microcystis aeruginosa NPCD-1 and Synechococcus sp. PCC7942. These authors reported viscosity values for microbial oils from cyanobacteria ranging between 52.7 and $62.3 \mathrm{cP}$ (at $50^{\circ} \mathrm{C}$ and deformation rate between 70 and $300 \mathrm{~s}^{-1}$ ). Similar results to those achieved by Da-Rós et al. [33] have also been reported by Carvalho [34], but for lipid produced by the filamentous fungus $M$. circinelloides URM 4182 and achieved viscosity of $60 \mathrm{cP}$ (at $50^{\circ} \mathrm{C}$ for deformation rate ranging between 60 and $260 \mathrm{~s}^{-1}$ ). These results show that lipids produced by yeasts may present lower viscosity than other microbial oils.

Acidity index is an important parameter for monitoring the quality of oils and fats. It reveals the degree of free fatty acids in the material, which is calculated in milligrams of potassium hydroxide to neutralize the free fatty acids present in one gram of sample. The oil produced by the yeast Rhodotorula glutinis NRRL Y-12905 achieved acidity index of $5.8 \pm 0.2 \mathrm{mg} \mathrm{KOH} / \mathrm{g}$ oil, which corresponds to $1.93 \% \pm 0.08 \%$ FFA. According to Porphy and Farid [35] using oils with an FFA content of over $5 \%$ in weight is not appropriate for transesterification by alkaline catalyzed, since the FFA can consume the catalyst and form soap that will cause serious biodiesel separation problems. Thus, the oil obtained herein presented free fatty acid content that makes it potentially feasible for biodiesel production by processes through an alkaline route. This characteristic of microbial oil is of great importance, since alkaline catalysis is the most widely used process nowadays, in addition to requiring milder processing conditions when compared to processes using acid catalysis.

\section{Conclusions}

Rhodotorula glutinis NRRL Y-12905 was able to produce and accumulate lipids from glycerol in all cultivation conditions evaluated herein; however, aeration and agitation proved to be important variables, since they were, in fact, capable of affecting the process efficiency.

As regards fermentation performance, the level of aeration has had a significant influence on substrate consumption, cell growth, lipid concentration and volumetric productivity. In general, cell growth, lipid accumulation and lipid volumetric productivity were favored by greater oxygen availability. Agitation and aeration at $250 \mathrm{rpm}$ and 5.0 (flask volume-to-medium volume ratio), respectively, were the optimal operational conditions in the evaluated range of values, due to promoting high cell and microbial oil concentrations $(39.4 \mathrm{~g} / \mathrm{L}$ and $4.5 \mathrm{~g} / \mathrm{L}$, respectively) and $\mathrm{Q}_{\mathrm{P}}(0.95 \mathrm{~g} / \mathrm{L} \cdot$ day $)$. These results demonstrate that the establishment of a suitable aeration condition is of paramount importance to improve the process of microbial oil production from glycerol by $R$. glutinis. In addition, glycerol bioconversion processes can provide a way of integrating with current biodiesel production, contributing to the development of lipid-based biorefinery. 


\section{Acknowledgements}

The authors gratefully acknowledge the financial support from FAPESP (Fundação de Amparo à Pesquisa do Estado de São Paulo-Process Number 2016/06683-0) and the CNPq (Conselho Nacional de Desenvolvimento Científico e Tecnológico-Process Number 455260/2014-1). This study was financed in part by the Coordenação de Aperfeiçoamento de Pessoal de Nível Superior-Brasil (CAPES)-Finance Code 001.

\section{Conflicts of Interest}

The authors declare that they have no conflict of interest.

\section{References}

[1] Jena, U., McCurdy, A.T., Warren, A., Summers, H., Ledbetter, R.N., Hoekman, S.K. and Quinn, J.C. (2015) Oleaginous Yeast Platform for Producing Biofuels via Co-Solvent Hydrothermal Liquefaction. Biotechnology for Biofuels, 8, 167. https://doi.org/10.1186/s13068-015-0345-5

[2] Carvalho, A.K.F.D. (2011) Síntese de biodiesel por transesterificação pela rota etílica: Comparação de desempenho de catalisadores heterogêneos. Doctoral Dissertation, Universidade de São Paulo, São Paulo.

[3] Canakci, M. and Sanli, H. (2008) Biodiesel Production from Various Feedstocks and Their Effects on the Fuel Properties. Journal of Industrial Microbiology \& Biotechnology, 35, 431-441. https://doi.org/10.1007/s10295-008-0337-6

[4] Quintana, N., Van der Kooy, F., Van de Rhee, M.D., Voshol, G.P. and Verpoorte, R. (2011) Renewable Energy from Cyanobacteria: Energy Production Optimization by Metabolic Pathway Engineering. Applied Microbiology and Biotechnology, 91, 471-490. https://doi.org/10.1007/s00253-011-3394-0

[5] Perez-Garcia, O., Escalante, F.M., de-Bashan, L.E. and Bashan, Y. (2011) Heterotrophic Cultures of Microalgae: Metabolism and Potential Products. Water Research, 45, 11-36. https://doi.org/10.1016/j.watres.2010.08.037

[6] Chisti, Y. (2007) Biodiesel from Microalgae. Biotechnology Advances, 25, 294-306. https://doi.org/10.1016/j.biotechadv.2007.02.001

[7] Soccol, C.R., Neto, C.J.D., Soccol, V.T., Sydney, E.B., da Costa, E.S.F., Medeiros, A.B.P. and de Souza Vandenberghe, L.P. (2017) Pilot Scale Biodiesel Production from Microbial Oil of Rhodosporidium toruloides DEBB 5533 Using Sugarcane Juice: Performance in Diesel Engine and Preliminary Economic Study. Bioresource Technology, 223, 259-268. https://doi.org/10.1016/j.biortech.2016.10.055

[8] Kong, W.B., Yang, H., Cao, Y.T., Song, H., Hua, S.F. and Xia, C.G. (2013) Effect of Glycerol and Glucose on the Enhancement of Biomass, Lipid and Soluble Carbohydrate Production by Chlorella vulgaris in Mixotrophic Culture. Food Technology and Biotechnology, 51, 62-69.

[9] Li, Y., Zhao, Z.K. and Bai, F. (2007) High-Density Cultivation of Oleaginous Yeast Rhodosporidium toruloides Y4 in Fed-Batch Culture. Enzyme and Microbial Technology, 41, 312-317. https://doi.org/10.1016/j.enzmictec.2007.02.008

[10] Tapia, E., Anschau, A., Coradini, A.L., Franco, T.T. and Deckmann, A.C. (2012) Optimization of Lipid Production by the Oleaginous Yeast Lipomyces Starkeyi by Random Mutagenesis Coupled to Cerulenin Screening. AMB Express, 2, 64. https://doi.org/10.1186/2191-0855-2-64 
[11] Hsieh, C.H. and Wu, W.T. (2009) Cultivation of Microalgae for Oil Production with a Cultivation Strategy of Urea Limitation. Bioresource Technology, 100, 3921-3926. https://doi.org/10.1016/j.biortech.2009.03.019

[12] Easterling, E.R., French, W.T., Hernandez, R. and Licha, M. (2009) The Effect of Glycerol as a Sole and Secondary Substrate on the Growth and Fatty Acid Composition of Rhodotorula glutinis. Bioresource Technology, 100, 356-361. https://doi.org/10.1016/j.biortech.2008.05.030

[13] Rawat, I., Kumar, R.R., Mutanda, T. and Bux, F. (2013) Biodiesel from Microalgae: A Critical Evaluation from Laboratory to Large Scale Production. Applied Energy, 103, 444-467. https://doi.org/10.1016/j.apenergy.2012.10.004

[14] Yazdani, S.S. and Gonzalez, R. (2007) Anaerobic Fermentation of Glycerol: A Path to Economic Viability for the Biofuels Industry. Current Opinion in Biotechnology, 18, 213-219. https://doi.org/10.1016/j.copbio.2007.05.002

[15] Swinnen, S., Klein, M., Carrillo, M., McInnes, J., Nguyen, H.T.T. and Nevoigt, E. (2013) Re-Evaluation of Glycerol Utilization in Saccharomyces cerevisiae: Characterization of an Isolate That Grows on Glycerol without Supporting Supplements. Biotechnology for Biofuels, 6, 157. https://doi.org/10.1186/1754-6834-6-157

[16] Li, Q., Du, W. and Liu, D. (2008) Perspectives of Microbial Oils for Biodiesel Production. Applied Microbiology and Biotechnology, 80, 749-756. https://doi.org/10.1007/s00253-008-1625-9

[17] Hall, M.J. and Ratledge, C. (1977) Lipid Accumulation in an Oleaginous Yeast (Candida 107) Growing on Glucose under Various Conditions in a One- and Two-Stage Continuous Culture. Applied and Environmental Microbiology, 33, 577-584.

[18] Zara, G., Angelozzi, D., Belviso, S., Bardi, L., Goffrini, P., Lodi, T., Mannazzu, I., et al. (2009) Oxygen Is Required to Restore Flor Strain Viability and Lipid Biosynthesis under Fermentative Conditions. FEMS Yeast Research, 9, 217-225. https://doi.org/10.1111/j.1567-1364.2008.00472.x

[19] Ageitos, J.M., Vallejo, J.A., Veiga-Crespo, P. and Villa, T.G. (2011) Oily Yeasts as Oleaginous Cell Factories. Applied Microbiology and Biotechnology, 90, 1219-1227. https://doi.org/10.1007/s00253-011-3200-Z

[20] Bligh, E.G. and Dyer, W.J. (1959) A Rapid Method of Total Lipid Extraction and Purification. Canadian Journal of Biochemistry and Physiology, 37, 911-917. https://doi.org/10.1139/o59-099

[21] Knight, J.A., Anderson, S. and Rawle, J.M. (1972) Chemical Basis of the Sulfo-Phospho-Vanillin Reaction for Estimating Total Serum Lipids. Clinical Chemistry, 18, 199-202.

[22] Ichihara, K.I. and Fukubayashi, Y. (2009) Preparation of Fatty Acid Methyl Esters for Gas-Liquid Chromatography. Journal of Lipid Research, 51, 635-640. https://doi.org/10.1194/jlr.D001065

[23] American Oil Chemists' Society (2004) Official Methods and Recommended Practices of the AOCS. 5th Edition, AOCS Press, Champaign.

[24] Saenge, C., Cheirsilp, B., Suksaroge, T.T. and Bourtoom, T. (2011) Potential Use of Oleaginous Red Yeast Rhodotorula glutinis for the Bioconversion of Crude Glycerol from Biodiesel Plant to Lipids and Carotenoids. Process Biochemistry, 46, 210-218. https://doi.org/10.1016/j.procbio.2010.08.009

[25] Coelho, M.A.Z., Amaral, P.F.F. and Belo, I. (2010) Yarrowia lipolytica: An Industrial Workhorse. Current Research, Technology and Education Topics in Applied Microbiology and Microbial Biotechnology, 2, 930-940. 
[26] Machado Junior, F.R.D.S. (2010) Conversão por via biotecnológica de glicerina residual em biomassa de leveduras como fonte de proteínas e lipídios. Master's Thesis.

[27] Magdouli, S., Brar, S.K. and Blais, J.F. (2018) Morphology and Rheological Behaviour of Yarrowia lipolytica: Impact of Dissolved Oxygen Level on Cell Growth and Lipid Composition. Process Biochemistry, 65, 1-10. https://doi.org/10.1016/j.procbio.2017.10.021

[28] Kot, A.M., Błażejak, S., Kurcz, A., Gientka, I. and Kieliszek, M. (2016) Rhodotorula glutinis-Potential Source of Lipids, Carotenoids, and Enzymes for Use in Industries. Applied Microbiology and Biotechnology, 100, 6103-6117. https://doi.org/10.1007/s00253-016-7611-8

[29] Sitepu, I.R., Sestric, R., Ignatia, L., Levin, D., German, J.B., Gillies, L.A. and Boundy-Mills, K.L. (2013) Manipulation of Culture Conditions Alters Lipid Content and Fatty Acid Profiles of a Wide Variety of Known and New Oleaginous Yeast Species. Bioresource Technology, 144, 360-369. https://doi.org/10.1016/j.biortech.2013.06.047

[30] Zhang, Z., Zhang, X. and Tan, T. (2014) Lipid and Carotenoid Production by Rhodotorula glutinis under Irradiation/High-Temperature and Dark/Low-Temperature Cultivation. Bioresource Technology, 157, 149-153.

https://doi.org/10.1016/j.biortech.2014.01.039

[31] Moreira, A.B., Perez, V.H., Zanin, G.M. and de Castro, H.F. (2007) Biodiesel Synthesis by Enzymatic Transesterification of Palm Oil with Ethanol Using Lipases from Several Sources Immobilized on Silica-PVA Composite. Energy \& Fuels, 21, 3689-3694. https://doi.org/10.1021/ef700399b

[32] Brock, J., Nogueira, M.R., Zakrzevski, C., de Castilhos Corazza, F., Corazza, M.L. and de OLIVEIRA, J.V. (2008) Determinação experimental da viscosidade e condutividade térmica de óleos vegetais. Ciência e Tecnologia de Alimentos, 28, 564-570. https://doi.org/10.1590/S0101-20612008000300010

[33] Rós, P., Da, C.M., Silva, C.S., Silva-Stenico, M.E., Fiore, M.F. and Castro, H.F.D. (2013) Assessment of Chemical and Physico-Chemical Properties of Cyanobacterial Lipids for Biodiesel Production. Marine Drugs, 11, 2365-2381. https://doi.org/10.3390/md11072365

[34] Carvalho, A.K.F.D. (2015) Avaliação do potencial do fungo filamentoso Mucor circinelloides como fonte de lipase e lipídios para a produção de biodiesel dentro do conceito de biorrefinaria. Doctoral Dissertation, Universidade de São Paulo, São Paulo.

[35] Porphy, S.J. and Farid, M.M. (2012) Feasibility Study for Production of Biofuel and Chemicals from Marine Microalgae Nannochloropsis sp. Based on Basic Mass and Energy Analysis. ISRN Renewable Energy, 2012, Article ID: 156824.

https://doi.org/10.5402/2012/156824 